\title{
Az 1. lovas-, a későbbi huszárhadosztály páncélosalakulatai a keleti fronton, 1944-ben
}

A z 1. lovashadosztály a Magyar Királyi Honvédség egyik büszkesége, és a kormányzó Horthy Miklós kedvenc alakulata volt. Azonban már az első világháború tapasztalatai megmutatták, hogy a nagy kötelékben alkalmazott lovasság felett elszállt az idő. Ugyanakkor a keleti fronton az összes hadviselő fél alkalmazott lovas magasabb egységeket. Az 1941-es harcok tapasztalatai alapján a magyar sereglovasságot is átszervezték, a két lovasdandárból, a három huszárezredből álló páncélosokkal, tüzérséggel és páncéltörő tüzérséggel megerősített lovashadosztályt alakítottak ki. Magyarország német megszállása után, német követelésre az 1. lovashadosztályt 1944. április 29-én mozgósították azzal a céllal, hogy bevessék őket a keleti fronton.

A magyar vezérkar eredetileg az 1. magyar hadsereg kötelékében kívánta alkalmazni a lovashadosztályt. A német hadvezetés döntése szerint a hadosztályt a Pripjaty folyó mocsaras területén vetették be. A német 2 . hadsereg tartalékaként kerültek a huszárok Walter Weiss altábornagy parancsnoksága alá. De nem sokáig maradtak tartalékban, hamarosan olyan harcokba vetették be őket, amelyekre szervezetüknél, fegyverzetüknél fogva alkalmatlanok voltak.

A hadosztály erői széttagoltan kerültek bevetésre. A 2. huszárezred alegységeit Luminniec körzetében partizánok ellen vetették be. A mocsaras területeken keresztül

1. ábra. $40 \mathrm{M}$ Turán közepes harckocsi. Az 1. lovas harckocsizászlóalj, a rombusz alakulat jelzésével

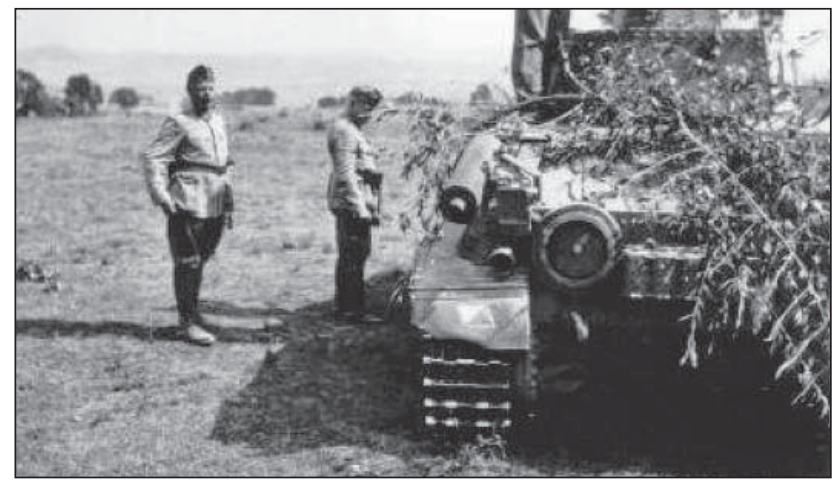

ÖSSZEFOGLALÁS: Az 1941-es harcok tapasztalatai alapján a két lovasdandárból egy három huszárezredből álló páncélosokkal, páncélgépkocsikkal, illetve légvédelmi-, tábori és páncéltörő tüzérséggel megerősített lovashadosztályt alakítottak ki. Magyarország német megszállása után az 1. Iovashadosztály bevetésre került a keleti fronton.

KULCSSZAVAK: Magyar Királyi Honvédség, 1. lovashadosztály

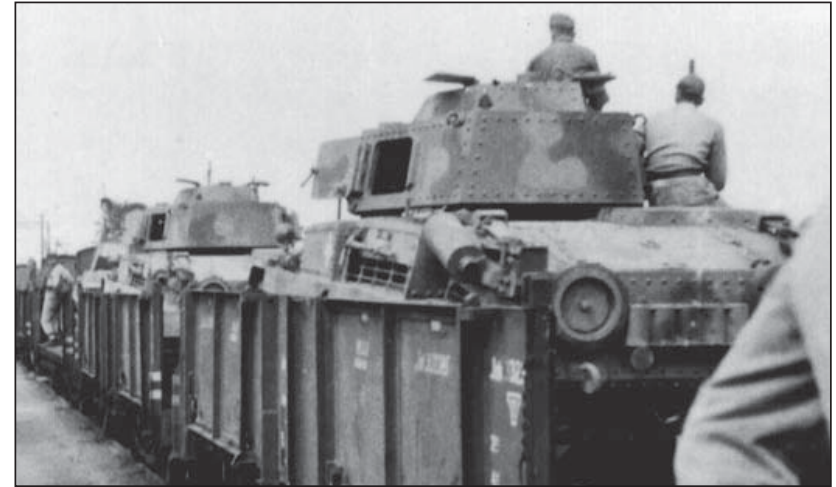

2. ábra. Az 1. lovas harckocsizászlóalj, 41M Turán nehéz harckocsik vasúti szállítása (1943)

még a lovasság számára is csak néhány út volt járható. A partizánok az utakat elaknásították és a mocsarakból intéztek támadásokat a huszárok ellen.

$A z$ 1. lovashadosztály kötelékében került a frontra az 1. lovas harckocsizászlóalj és a 3. felderítő-zászlóalj is. Ezeket a zászlóaljakat a korábbi két lovas páncéloszászlóalj bázisán szervezték meg és töltötték fel.

$A z$ 1. lovas harckocsizászlóalj egy nehéz, három közepes és egy törzsszázadból állt, állományába összesen 25 darab 38M Toldi könnyű harckocsival, 54 darab 40M Turán közepes és 11 darab 41M Turán nehéz harckocsival. Más források szerint 56 darab közepes és 11 darab nehéz Turán harckocsival, 5 darab Toldi könnyű harckocsival és 3 darab Škoda 38(t), csak kiképzésre használt harckocsival rendelkezett a zászlóalj.

A 3. felderítő-zászlóaljnak két páncélgépkocsi-százada volt, egyenként 13 darab 39M Csaba páncélgépkocsival és 40M Csaba parancsnoki rádiós páncélgépkocsival. A felderítő-zászlóaljnak összesen 27 darab páncélgépkocsija volt, ebből 1 darabot a zászlóaljtörzsbe osztottak be. Egyes források alapján csak 23 darab páncélgépkocsival került ki a frontra a felderítő-zászlóalj.

$A z$ 1. lovashadosztály kötelékébe tartozó 15 . kerékpáros zászlóalj egy páncélgépágyús szakasszal rendelkezett, 4 darab 40M Nimród páncélgépágyúval.

ABSTRACT: Based on experience gained from battles in 1941, a cavalry division composed of two cavalry brigades and three hussar regiments, and strengthened with tanks, armoured cars, anti-aircraft artillery, field and antitank artillery was established. Following German occupation of Hungary, the 1st Cavalry Division was deployed on the eastern front.

KEY WORDS: Royal Hungarian Army, 1st Cavalry Division

\footnotetext{
Nyá. ezredes, ORCID: 0000-0003-2199-3673
} 


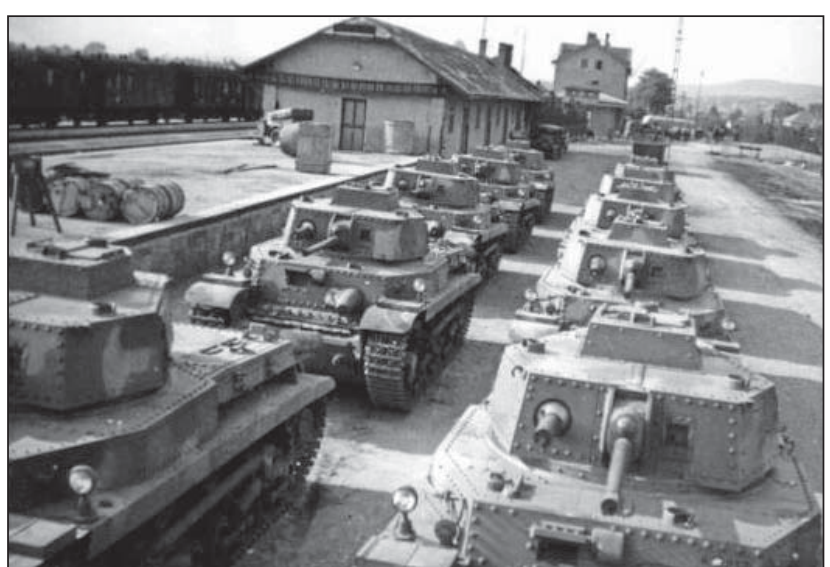

3. ábra. Az 1. lovas harckocsizászlóalj 40M Turán harckocsijai vasúti szállításra várnak Hajmáskéren

Makay István vezérőrnagy (a lovashadosztály parancsnokhelyettese) parancsnoksága alatt a 4 . huszárezredet, a 15. kerékpáros zászlóaljat és a 3 . tüzérosztályt a német XXIII. hadtestnek rendelték alá.

Makay István vezérőrnagy Krupp Protze parancsnoki gépkocsija Orly térségében a partizánok által telepített aknára futott. A vezérőrnagy meghalt, míg a többi utas súlyos sérüléseket szenvedett. Utóda, Schell Zoltán ezredes lett. Makay vezérőrnagyot 1944 szeptemberében posztumusz altábornaggyá léptették elő. Ő volt a magyar honvédség legmagasabb rangú tisztje, aki harctéren hősi halált halt.

Ugyanezen a napon indította meg a Vörös Hadsereg a Bagratyion offenzívát. Ennek során a szovjet csapatok célja a német középső hadseregcsoport szétzúzása volt, amelynek kötelékében az 1. lovashadosztály és a II. tartalékhadtest is harcolt.

1944. június 23-án a szovjet csapatok áttörték a német vonalakat. A lovashadosztály egységeit - közvetlen német irányítás alatt - ettől kezdve már a reguláris szovjet erők ellen is bevetették.

A huszárok támogatására bevetették az 1. lovas harckocsizászlóalj századait is. 1944. július 2-án a lovas harckocsizászlóalj erőiből két harccsoportot alakítottak. A 4. nehéz harckocsiszázadot a Schell Zoltán ezredes parancsnoksága alatt Timkovicze körzetében harcoló erőknek rendelték alá. Schell ezredes harccsoportja a következő erőkből állt: másfél huszárezred, két és fél tüzérosztály, egy légvédelmi üteg, egy nehézharckocsi-század, egy páncélgépkocsi-szakasz. A huszárokat egy német páncélvadász-század is támogatta.

A Schell-harccsoportnak kellett felváltani a Timkovicze hídfőben harcoló német 4 . lovashadosztály alakulatait. Az

4. ábra. A 15. kerékpáros zászlóalj 40M Nimród páncélgépágyúja, a hadosztály lópatkó jelzésével

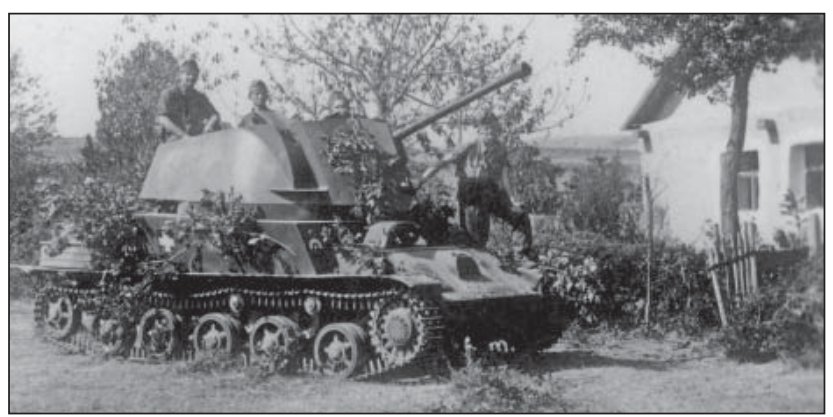

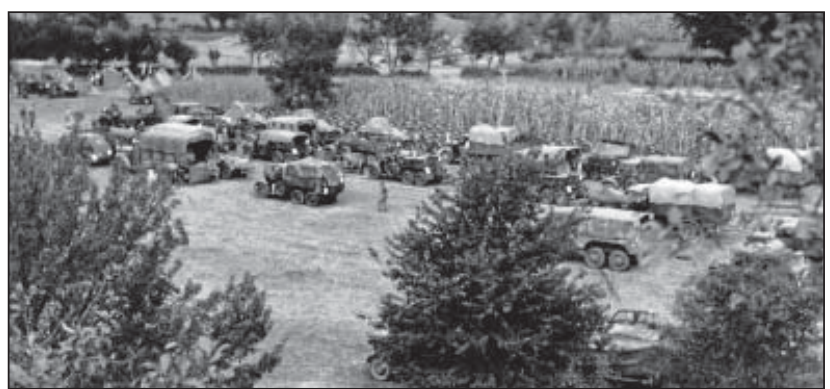

5. ábra. A lovashadosztály 3. felderítő-zászlóaljának járművei

1. lovas harckocsizászlóalj zöme és a 3. felderítő-zászlóalj Kleck térségében tartalékban várakozott.

1944. július 3-án a Schell-harccsoport erői Timkovicze irányából támadást indítottak az ellenséges erők ellen. A támadó huszárokat Smolice és Kuderewszczyzna térségéből szovjet harckocsi ellentámadás érte. A 4. nehézharckocsi-század, Reök Attila százados parancsnoksága alatt, sikeresen elhárította a szovjet harckocsik támadását.

Elkeseredett harcok után a lovashadosztály egységeit Kleck térségében bekerítette a Vörös Hadsereg. A huszárok parancsot kaptak a kitörésre és a visszavonulásra a Cepra patak mögé. A július 4-én indult kitörést a 4. nehézharckocsi-század harcjárművei vezették. Reök százados előrenyomuló $41 \mathrm{M}$ Turán nehéz harckocsijait a 4. árkászszázad Panzerfaust kézi páncéltörő rakétavetőkkel felszerelt utászai támogatták.

Schell Zoltán ezredes így emlékezett a támadásra:

„A Cepra hídjának közelében a dombtetőn álltam. Ekkor ért oda élével az északkelet felöl visszaérkező gépkocsizó utászszázad, észak felöl jövet pedig Reök százados nehéz harckocsi százada. Parancsnokaik éppen jelentkeztek. Ebben a pillanatban a tőlünk néhány száz méterre északkelet felé eső dombvonulat peremén több ellenséges harckocsi jelent meg és kezdett tüzelni minden mutatkozó célra: reánk, az utászokra, a Cepra menti felvételi állás csapataira, sőt a domb felett átcsúszó tüzérségi lövedékek a mögöttünk elterülö lapályon álló lovas és vezeték ló csoportok között robbantak, kavarodást okozva soraikban. Elérkezett a nap legválságosabb pillanata. Sok gondolkodásra nem volt idő. Intézkedéseim nagyon rövidek voltak:

1. Reök századosnak a nehézharckocsiszázad parancsnokának személyesen: „Támadás! Irány az ellenség! A dombtetőn állj!«

2. Szaller századosnak a gépkocsizó utászszázad parancsnokának szintén személyesen: "Gépkocsiról! A harckocsi századot követve fel a dombra! Ott páncél védelem!«

3. Szabadhegy alezredesnek - ki a mögöttünk elterülő lapályon osztályának kötelékeit rendezte, - motorkerékpáros hírvivővel: „A 4/11. huszárosztály lóra! Visszavonulás ügetésben le délre a müútig! Ott Matuskovich örnagytól kap további parancsot!«

4. Matuskovich örnagynak személyesen: »,Motorkerékpáron le a müútig! A hídnál feltartóztatni a visszavonuló kötelékeket és tovább irányítani a müúton nyugat felé Sinjavka területére. Az elsőül beérkező század biztosít kelet és dél felé! Felderitést kirendelni a mü-út mindkét oldalára! Makay ezredest itt bevárom, azután jövök le a müútra. Ha a Ceprá-n innen ellenség volna, áttörünk rajta!« Még nem is végeztem Matuskovich örnaggyal, már is dübörögtek Reök százados harckocsijai fel a dombra, nyomukban az utászok páncélöklökkel. Néhány páncéltörő ágyú gyorstüzet zúdított az ellenséges harckocsikra, melyek nyomban visszahúzódtak a fedező peremvonal mögé. Harckocsijaink nem álltak meg a dombtetön, hanem heves tüzelés közepette 


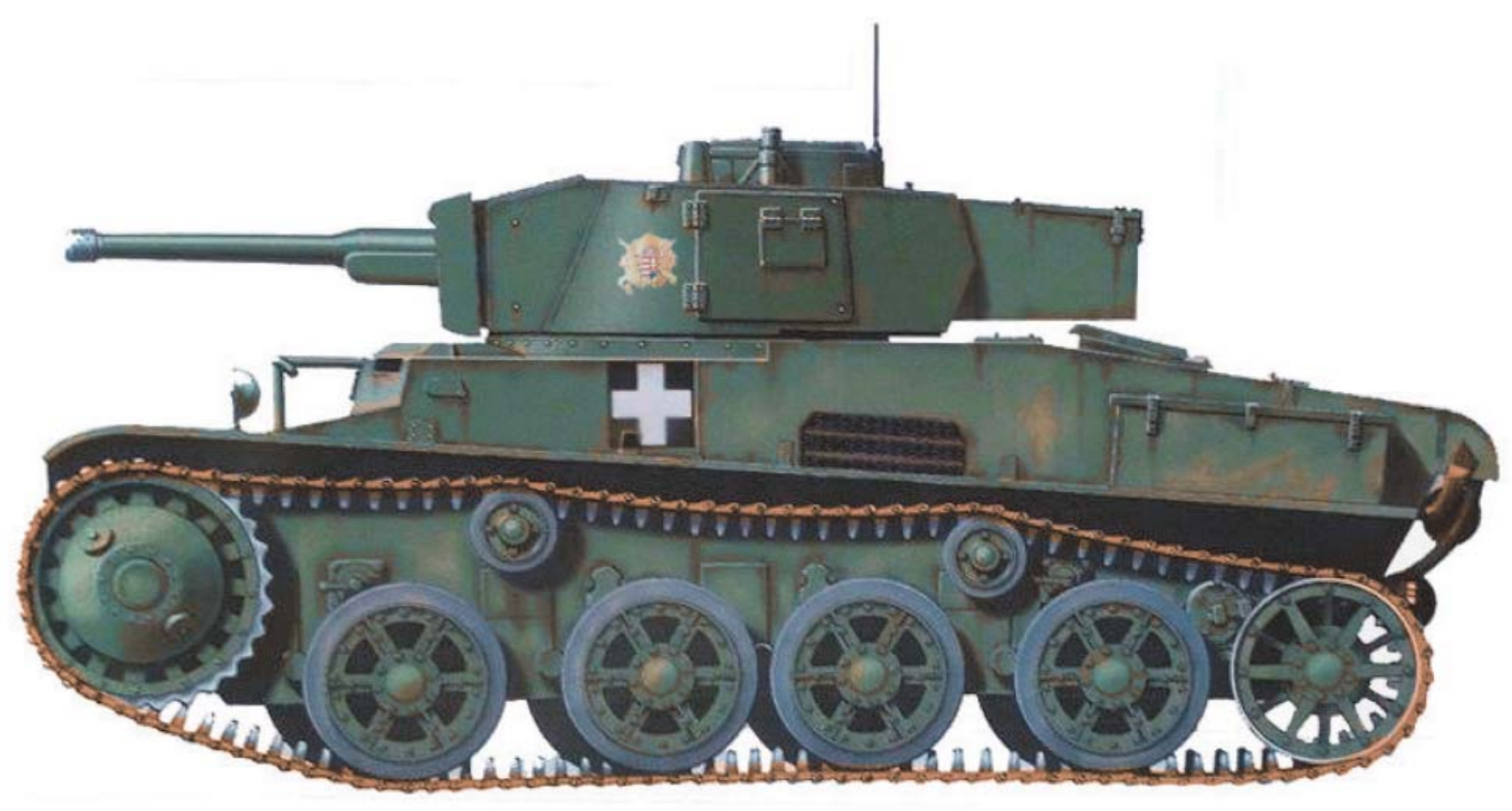

6. ábra. Az 1. lovas harckocsizászlóalj ágyús, 38M Toldi-Il-es harckocsija

nyomon követték a menekülö ellenséget, több harckocsit kilőttek és visszaverték az ellenséges páncélos élt követő, gyalogságtól kísért erősebb páncélos egységet is. Az ellenség két harckocsinkat kilötte és a századparancsnoki harckocsi nyitott páncél-tornyában álló Reök százados súlyosan megsebesült, fél karját vesztette.

Ma is feldobog a szívem, ha visszagondolok vitéz Reök százados páncélosaira és Szaller százados utászaira. Felejthetetlenül elöttem áll hősies rohamuknak képe. Nem tudták, hogy milyen erős az ellenség, nem tudták mi vár rájuk a dombvonulaton túl, de habozás nélkül villámgyorsan rontottak a szovjet páncélosokra, hogy megmentsék a helyzetet. És megmentették!"

1944. július 13-án a támadó szovjet erők beékelődtek a 3. huszárezred és a német 102. gyalogezred védőállásai közé. A 15. kerékpáros zászlóalj alegységei Buzuny körzetéből támadást intéztek Mielniki irányába a beékelődött orosz csapatok kiverésére. A kerékpáros honvédek kézitusában, feltűzött szuronnyal és kézigránátokkal állították vissza az eredeti helyzetet.

A klecki hadműveletek után, 1944. július 25-éig a lovashadosztály csapatai folyamatosan visszavonultak a Visztula irányába.

A hadosztály csapatai súlyos személyi és anyagi, technikai veszteségeket szenvedtek. Az1. lovas harckocsizászlóalj mind a 84 harckocsiját elvesztette a harcok következtében. Július 15-én a harckocsik nélkül maradt legénységből két gyalogszázadot szerveztek. A 3. felderítő-zászlóaljnak mindössze 6 darab Csaba páncélgépkocsija maradt a kivonult 23-ból.

1944. július 15-éig a lovashadosztály személyi veszteségei a következőképpen alakultak: a 2. huszárezred 40\%-át, a 4. huszárezred 30\%-át, a 15. kerékpáros zászlóalj 40\%₹át, az 1. lovas harckocsizászlóalj 35\%-át vesztette el.

1944 augusztusában az Ibrányi Mihály vezérőrnagy parancsnoksága alatt álló 1 . lovashadosztályt átszervezték és részben átfegyverezték német gyalogsági és nehézfegyverekkel. A 2. huszárezred kapta a német gyalogsági könnyüés nehézfegyvereket és a PAK40-es páncéltörő ágyúkat. A 2. huszárezred megtartotta eredeti lovas szervezetét. A 3. és 4. huszárezredeknél egy-egy lovas és gyalogosított huszárosztályt szerveztek. A hadosztályt megerősítették német páncélvadászokkal is. A hadosztály páncélos alegységeit - feltehetően harcjármű hiányában - kivonták a hadrendből.
A huszárhadosztály alakulatai 1944-1945-ben részt vettek a magyarországi harcokban, az alakulat maradványai 1945 márciusában, Ausztriában megadták magukat az amerikai csapatoknak.

\section{FORRÁSOK}

Huszár Hadosztály 1944/45, HHA, 1992;

A m. kir. fegyveres erők képeskrónikája (1919-1945), Vitézi Szék, 1977;

Adonyi-Náredny Ferenc - Nagy Kálmán: Magyar huszárok a II. Világháborúban, HHA, 1990;

Bíró Ádám - Éder Miklós - Sárhidai Gyula: A Magyar Királyi Honvédség külföldi gyártású páncélos harcjármúvei 1920-1945, Petit Real, 2006;

Bíró Ádám - Éder Miklós - Sárhidai Gyula: A Magyar Királyi Honvédség hazai gyártású páncélos harcjármüvei 1920-1945, Petit Real, 2012;

Bonhardt Attila - Sárhidai Gyula - Winkler László: A Magyar Királyi Honvédség fegyverzete 1919-45, 1. rész, Zrínyi, 1992;

Dálnoki Veress Lajos: Magyarország honvédelme a II. világháború előtt és alatt (1920-1945), München, 1974;

Dombrády Loránd - Tóth Lajos: Magyar Királyi Honvédség 1919-45, Zrínyi, 1987;

Csima János: Források a Magyar Honvédség II. világháborús történetének tanulmányozásához, Zrínyi, 1961;

Gosztonyi Péter: A Magyar Honvédség a II. világháborúban, Európa, 1992;

Görgey Vince: Páncélosok előre!, Stádium, 1942;

Splényi: Az utolsó magyar huszárok, Magyar Huszár Egyesület (HHA), 1996;

Szabó Péter - Számvéber Norbert: A keleti hadszíntér és Magyarország, Puedlo;

Dombrándy Loránd: A horthysta katonai vezetés erőfeszítései a páncélos fegyvernem megteremtésére, Hadtörténeti Közlemények 1969/2., 1970/4.;

Szabó Kristóf: A 101. önáló harckocsi század vázlatos története, Katona Újság 2011/5.;

Péter Mujzer: Hungarian Mobile Forces 1920-45, Bayside Books, 2000.

Dr. Varga A. József (szerk.): Magyar autógyárak katonai jármúvei Budapest; Maróti könyvkerekedés és könyvkiadó Kft, 2008. 